\title{
Impact of controlled atmosphere scheduling on strawberry and imported
}

\section{avocado fruit}

\author{
M. Carmen Alamar, Emma Collings, Katherine Cools, Leon A. Terry* \\ *1.a.terry@cranfield.ac.uk
}

Plant Science Laboratory, Cranfield University, Bedfordshire, UK, MK43 OAL

\begin{abstract}
British grown strawberry cv. Sonata and Chilean avocado cv. Hass were exposed to controlled atmospheres $(\mathrm{CA})$ of $15 \mathrm{kPa} \mathrm{CO}_{2}+5 \mathrm{kPa} \mathrm{O} 2\left(5^{\circ} \mathrm{C}\right)$ and $10 \mathrm{kPa} \mathrm{CO}+5 \mathrm{kPa} \mathrm{O}_{2}(5$ or $20^{\circ} \mathrm{C}$ ), respectively, at early, middle or late stages during postharvest storage of avocados and at early and middle stages for strawberries. Real-time respiration rate (RR) was measured during CA storage and regular fruit sampling carried out to assess disease severity, objective colour, ethylene production and firmness. The automated in situ set-up used allowed continuous recordings of real-time respiration measurements without disruption to the CA environment. Cold stored strawberry fruit treated for $2.5 \mathrm{~d}$ with CA midway through the storage period were firmer and maintained a more vibrant colour despite bursts of increased RR. Furthermore, just $2.5 \mathrm{~d}$ of CA was sufficient to extend the shelf-life of strawberries (based on disease incidence) by a further $3 \mathrm{~d}$, as compared to control. Irrespective of timing, RR of avocado stored at $20{ }^{\circ} \mathrm{C}$ was reduced while under CA environment; and early CA exposure maintained firmness yet increased the incidence of internal discolouration $7 \mathrm{~d}$ after removal from CA. At $5{ }^{\circ} \mathrm{C}$, avocado skin colour and internal discolouration were positively affected by the mid CA treatment. These results are discussed in the context of the targeted use of CA, compared to control, for extending shelf-life, and reducing waste of these two different fruit produces. Furthermore, reducing the length of time required for CA application, which has not
\end{abstract}


previously been explored in avocado or strawberries, would potentially be more energy efficient / cost effective.

Keywords: Respiration rate; Food quality; Food waste

\section{Introduction}

With an ever-increasing global population, new methods to improve food availability and reduce waste have become a priority. One significant cause of food losses occurs when food quality is compromised due to inefficient post-harvest handling, including inappropriate gas storage composition and packaging (Terry et al., 2011).

Strawberries (Fragaria x ananassa Duch.) and imported avocado (Persea americana Mill.) are two high value but contrasting fresh produce types available in the UK, with remarkable differences not only in their physiology but also in their supply chain. In the UK market, a significant proportion of strawberry fruit are grown in the UK so that berries can reach the retailer and consumer within 4-7 d from harvest. Whilst, imported avocado undergo a long transit period ( $c a$. one month by boat) from the Southern Hemisphere (viz. South America, South Africa) before arriving at British packing houses, where they can be further stored, ripened and packaged. These two produce types also vary significantly in their physiology and metabolic responses during ripening. For instance, as a climacteric fruit, the respiration rate of avocado can exceed $184 \mathrm{mg} \mathrm{kg}^{-1} \mathrm{~h}^{-1}$ at $20{ }^{\circ} \mathrm{C}$ at the onset of ripening (ValleGuadarrama et al., 2013) coinciding with high levels of ethylene production $\left(\geq 1180 \mu \mathrm{g} \mathrm{kg}^{-1} \mathrm{~h}^{-}\right.$ 1; Valle-Guadarrama et al., 2013; Basuki et al., 2016). In contrast, strawberry fruit, which are currently classed as non-climacteric, produce lower levels of $\mathrm{CO}_{2}$ (up to $c a .129 \mathrm{mg} \mathrm{kg}^{-1} \mathrm{~h}^{-1}$ at $23{ }^{\circ} \mathrm{C}$ ) and significantly lower levels of ethylene (Kader 2002; Thompson 2003; Terry et al, 
2007). Consequently, these two perishable products provide a useful comparison for gas exchange under different storage conditions including controlled atmosphere (CA).

Low temperature $\left(<5^{\circ} \mathrm{C}\right)$ is widely used to extend strawberry and avocado storability (Kader 2002; Thompson 2003; Castellanos et al., 2017). However, cold storage alone is often not sufficient to store and transport produce such as avocados between intercontinental markets. Furthermore, cold storage of avocado fruit can lead to chilling injury (CI) (Basuki et al., 2016). Optimum CA conditions for normal ripening of avocado are between 2.5 and $5 \mathrm{kPa}$ $\mathrm{O}_{2}$, and 5 and $7.5 \mathrm{kPa} \mathrm{CO}$, yet incidence of CI was not retarded (Basuki et al., 2016). CA environments (e.g. high $\mathrm{CO}_{2}$ ) are known to reduce microbial decay (viz. Botrytis cinerea) in strawberries (Almenar et al., 2006; Barrios et al., 2014) and stem-end rot (viz. Botryodiplodia theobromae and Lasiodiplodia theobromae) in avocado (Pesis et al., 2002). However, levels exceeding $15 \mathrm{kPa} \mathrm{CO}_{2}$ can result in $\mathrm{CO}_{2}$ injury (Barrios et al., 2014).

Depending on the type of produce, metabolic state can significantly vary throughout storage resulting in different challenges for MAP and CA storage. Use of CA to maintain quality of both strawberry and avocado have been developed, but limitations still exist. The efficacy of CA is affected by avocado maturity and cultivar differences which can lead to a build-up of $\mathrm{CO}_{2}$ and ethylene if gas exchange is not sufficient (Meir et al., 1997; Hertog et al., 2003). Thus, high levels of ethylene generated during the climacteric increase can hasten ripening and senescence. Therefore, successful storage under CA or MAP would require an environment/packaging with rapid gas exchange (Espinosa-Cruz et al., 2014). Strawberry fruit, on the other hand, despite their lower ethylene and $\mathrm{CO}_{2}$ levels, are highly perishable and especially prone to postharvest disease; hence market shelf-life is very limited. There is a paucity of up to date research investigating the effects of $\mathrm{CA}$ on the respiration rate of strawberry and avocado throughout the supply chain and during post-harvest storage. Furthermore, there is a lack of information on how the application of differential CA 
environments during post-harvest life could conserve strawberry and avocado quality. Targeted CA application has previously been found to be as effective as continuous CA to extend shelflife of onion during cold storage (Chope et al., 2007); however, this has not been explored for avocado or strawberry fruit. Understanding the effects of respiratory gases on fruit physiology is key to the development of optimum packaging to extend post-harvest shelf-life (Castellanos et al., 2017). The objective of this work was to use real time respiration rate technology as a tool to assess physiological changes throughout cold storage and shelf life of both imported avocado and UK-grown strawberry fruit, and to elucidate the impact of physiologically targeted CA on industrially relevant quality attributes (viz. firmness and visual appearance/colour) of both produce types. These findings could provide a better understanding of gas exchange under a CA environment allowing the industry to better maintain quality and reduce waste.

\section{Materials and methods}

\subsection{Plant material}

Strawberries cv. 'Sonata' were grown at PR \& ON Harrold Farm in Milton, Cambridgeshire and harvested in the early morning on $2^{\text {nd }}$ June 2014. Strawberries were immediately cooled down to $2-5^{\circ} \mathrm{C}$ and transported to Cranfield University by midday in an air-conditioned vehicle $(1 \mathrm{~h})$. Fruit were immediately transferred to the treatment boxes upon arrival at the Plant Science Laboratory.

Avocado fruit (cv. Hass, size 22) grown at Agricola la Cascada, Chile, were harvested on the $16^{\text {th }}$ October $2013\left(20^{\circ} \mathrm{C}\right.$ trial $)$ and $4^{\text {th }}$ December $2013\left(5^{\circ} \mathrm{C}\right.$ trial $)$, and packed at Central Fructicola El Parque, Chile, within 2 d. Avocados were palletised and shipped to the UK at 6 ${ }^{\circ} \mathrm{C}$ under a high nitrogen environment (typically $94 \% \mathrm{~N}_{2}, 4 \% \mathrm{CO}_{2}$ and $2 \% \mathrm{O}_{2}$ ). The fruit arrived at Worldwide Fruits Ltd. (Pinchbech, Lincs.) approximately one month after harvest: on $19^{\text {th }}$ November and $6^{\text {th }}$ January 2014, respectively. Pre-climacteric avocados (average hue angle: 
122 and 120; average firmness: 218 and $215 \mathrm{~N}$, for November and January arrivals, respectively) were transported $(2 \mathrm{~h})$ from Worldwide Fruit Ltd. to Cranfield University on $25^{\text {th }}$ November 2013 and $17^{\text {th }}$ January 2014 for $20^{\circ} \mathrm{C}$ and $5{ }^{\circ} \mathrm{C}$ trials, respectively; and immediately transferred to the treatment boxes (no physiological disorders were observed at arrival).

\subsection{Experimental design}

\section{Controlled atmosphere scheduling}

Five small plastic containers (punnet) holding $c a .400 \mathrm{~g}$ of strawberries (18-20 berries) were placed into 12 Lock \& Lock $12 \mathrm{~L}(315$ x 230 x $230 \mathrm{~mm})$ polypropylene boxes (L\&L Nordic OÜ, Estonia), and further stored at $5^{\circ} \mathrm{C}$ for $14 \mathrm{~d}$. Storage conditions were: (a) $15 \mathrm{kPa}$ $\mathrm{CO}_{2}+5 \mathrm{kPa} \mathrm{O}$ for $2 \mathrm{~d}$ followed by air for the remaining storage period; (b) air for $2 \mathrm{~d}$ followed by $15 \mathrm{kPa} \mathrm{CO} 2+5 \mathrm{kPa} \mathrm{O}$ for $2.5 \mathrm{~d}$ and air for the remaining storage duration; and (c) air only (Figure 1a).

For the $20^{\circ} \mathrm{C}$ avocado trial, fruit $(n=20)$ were placed into identical $12 \mathrm{~L}$ storage boxes, as described above. CA conditions were $10 \mathrm{kPa} \mathrm{CO} 2+5 \mathrm{kPa} \mathrm{O}$. Treatments applied were as follows: (a) CA for $2 \mathrm{~d}$ followed by air; (b) $1.5 \mathrm{~d}$ of air followed by $2 \mathrm{~d}$ of CA and then transferred back to air; (c) air for $3 \mathrm{~d}$ followed by CA for $2 \mathrm{~d}$, and then transferred back to air; and (d) air only (Figure 1b). For the $5{ }^{\circ} \mathrm{C}$ storage trial, the treatments were (a) CA for $5 \mathrm{~d}$ followed by air; (b) $5 \mathrm{~d}$ of air followed by $5 \mathrm{~d}$ of CA, then transferred back to air; (c) air for 10 $\mathrm{d}$ followed by CA for $5 \mathrm{~d}$, then transferred back to air; and (d) air only (Figure 1c). Avocado fruit were held at $20{ }^{\circ} \mathrm{C}$ for $9 \mathrm{~d}$ and at $5{ }^{\circ} \mathrm{C}$ for $30 \mathrm{~d}$. After $30 \mathrm{~d}$ at $5{ }^{\circ} \mathrm{C}$, the avocados were transferred to $20^{\circ} \mathrm{C}$ for $4 \mathrm{~d}$ to mimic standard shelf-life conditions.

For the strawberry and avocado cold storage experiments $\left(5^{\circ} \mathrm{C}\right)$, and the room temperature $\left(20^{\circ} \mathrm{C}\right)$ avocado trial, the duration of the CA period ( 2 and $5 \mathrm{~d}$, respectively) was 
selected on the basis of desired commercially-relevant increases in shelf-life, in consultation with industry stakeholders.

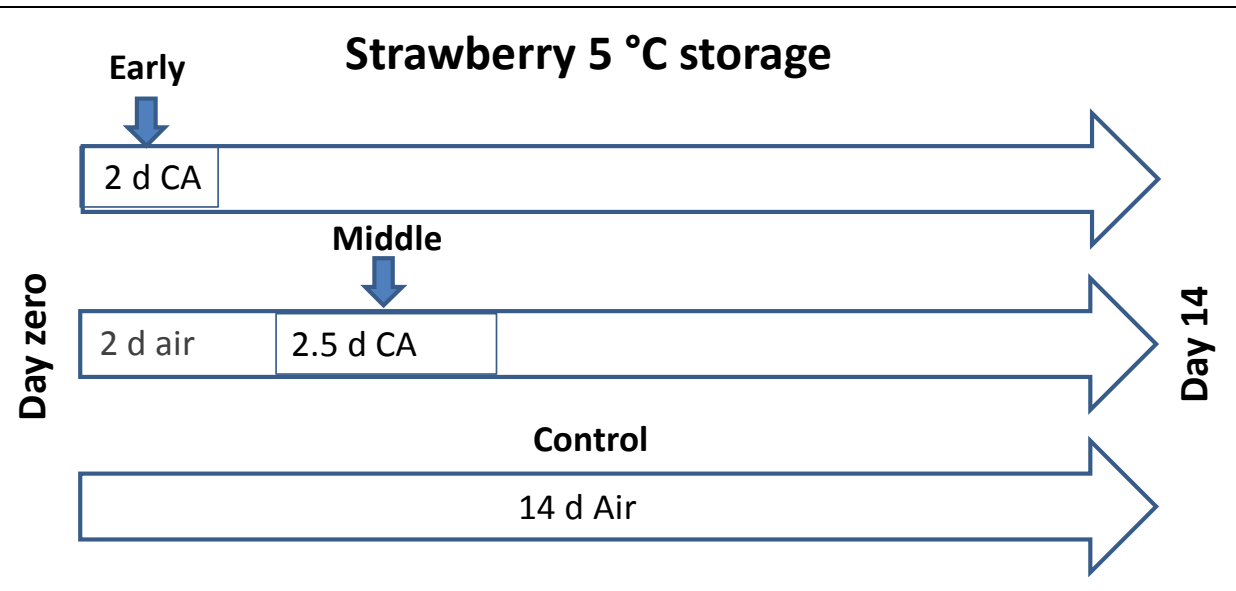

$\mathbf{a}$

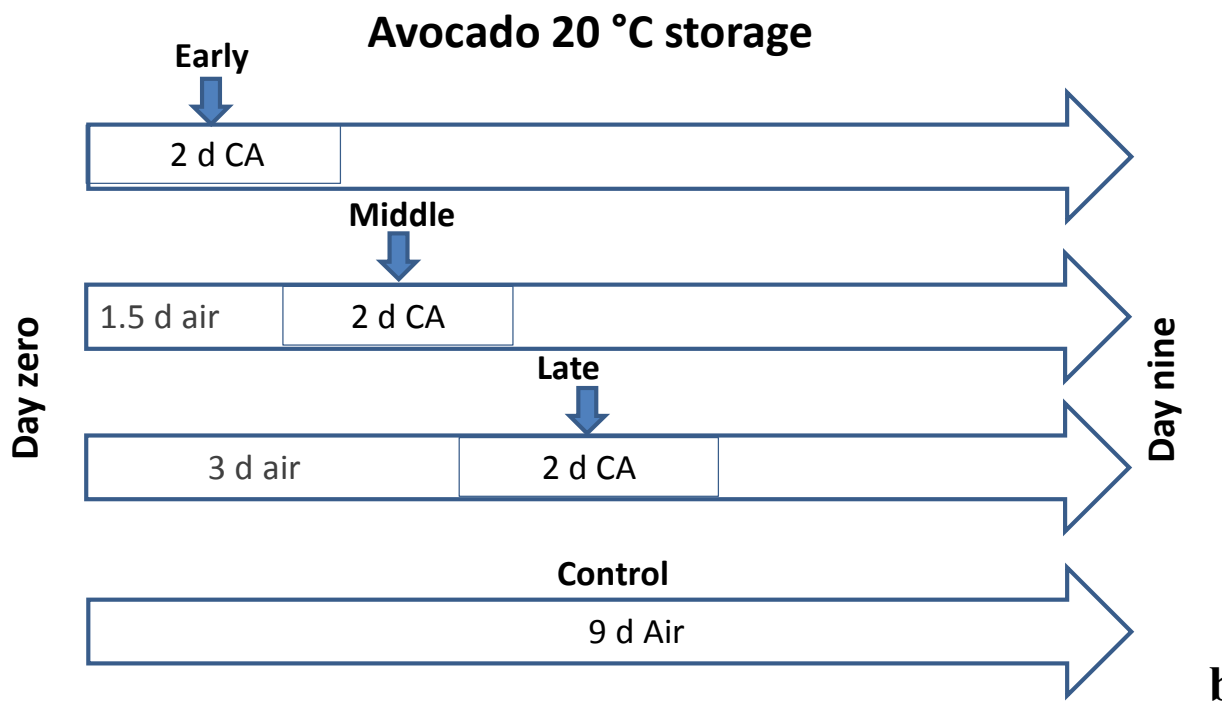




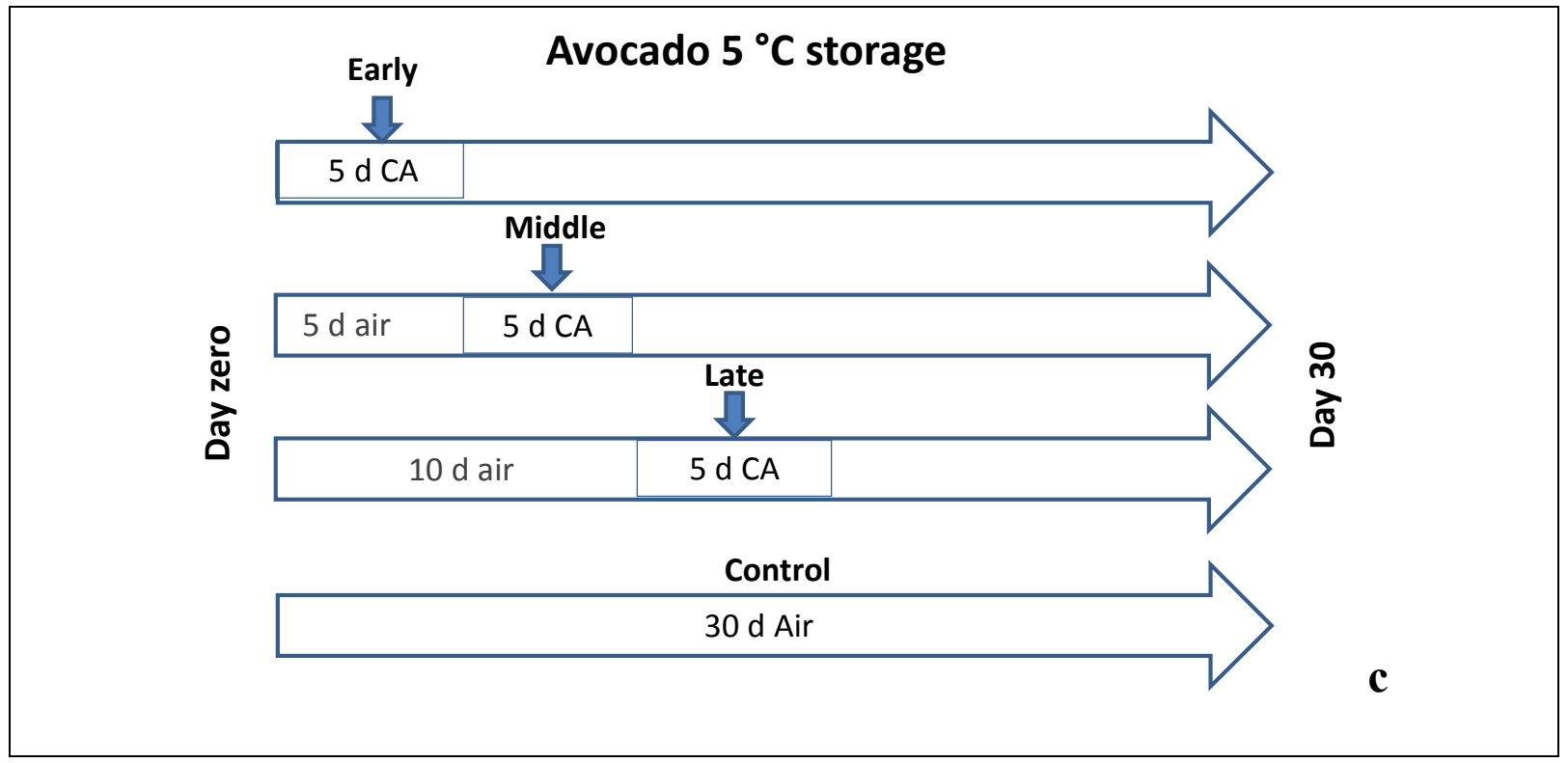

Figure 1. Schematic of controlled atmosphere scheduling for strawberry (a) and imported avocado fruit stored at $5{ }^{\circ} \mathrm{C}\left(\right.$ b) and $20^{\circ} \mathrm{C}$ (c) for different time periods (days [d]).

\section{Real-time respiration rate set-up}

For each CA condition, four storage containers were connected via PVC tubing to one channel of an ICA6000 (International Controlled Atmosphere Ltd., Paddock Wood, Kent, UK) (CA control system with up to eight channels connected to in-built gas analysers); each channel was split into four, providing a continuous flow $\left(400 \mathrm{~mL} \mathrm{~min}^{-1}\right)$ to three replicate boxes and one baseline box (empty). The exiting flow was passed directly to a Sable Respirometry System (Model 1.3.8 Pro, Sable Systems International, Las Vegas, NV) and real-time respiration rate measurements (as $\mathrm{CO}_{2}$ production) continuously recorded (Section 2.3). The change in sample weight within each storage container was measured at each sampling point throughout storage to adjust respiration rate calculations, accordingly.

\subsection{Physiological measurements}

Sample preparation 
Fruit were sampled prior to CA treatment application (time zero) and at regular intervals throughout storage, thereafter. At time zero, four individual strawberry fruit (pseudo replicates) were taken per sampling punnet, in triplicate $(n=12$ fruit); a total of nine avocado fruit (3 fruit [pseudo replicate] x 3 replicates) were analysed at this point. After time zero, one punnet of strawberries was removed from each storage box after 2, 4.5, 8, 11 and $14 \mathrm{~d}$ of cold storage at $5{ }^{\circ} \mathrm{C}$. Physiological measurements, including disease assessment, were performed on four fruit from each punnet. For avocado, three fruit were taken from each storage box on a weekly basis for the fruit stored at $5{ }^{\circ} \mathrm{C}$ and three times per week for the avocados at $20{ }^{\circ} \mathrm{C}$ (zero, two, four, and seven). For all physiological measurements (e.g. colour, firmness and disease incidence/severity), the mean value from the pseudo replicates (4 strawberries per punnet and 3 avocados from each of the storage boxes) was considered for further statistical analysis.

\section{Respiration rate measurements}

Continuous real time respiration rate measurements were acquired using a Sable Respirometry System (model 1.3.8 Pro, Sable Systems International, NV, USA) as described in Collings et al. (2013) with slight modifications. Air from each storage box was passed directly to the system using 'push mode' and measured for 2 min. Automated switching between boxes was achieved using the Sable System MUX flow multiplexer. Sampled air was passed through a SS4-subsampler (Firmware version 2.0), RH-300, CA-10 (Firmware version 1.05) and a FC-10 (Firmware version 3.0) to record flow rate $\left(\mathrm{mL} \mathrm{h}^{-1}\right)$, water vapour pressure, $\mathrm{CO}_{2}(\mathrm{kPa})$ and $\mathrm{O}_{2}(\mathrm{kPa})$, respectively. Barometric pressure $(\mathrm{BP}[\mathrm{kPa}])$ was simultaneously recorded using the CA-10. Cross contamination between measurements was prevented using empty baseline boxes assigned per gaseous environment (viz. air [control] vs. CA), which enabled initial $\mathrm{O}_{2}$ and $\mathrm{CO}_{2}$ levels to be accurately determined for subsequent respiration rate calculations. Due to lag time and extreme differences in gas composition between air and CA 
treatments, baseline boxes were sampled for three consecutive intervals of 2 min allowing equilibration prior to measuring a different $\mathrm{CA}$ condition. A 2 min baseline interval was adequate for replicate boxes within treatments. Baseline values were later subtracted from sample measurements to accurately determine respiration rate. Software calculations were performed as described previously in Collings et al. (2013).

Objective colour, ethylene production and firmness

At each sampling point, objective colour was assessed using a Minolta colorimeter (CR-400 series, Konica Minolta Inc., Japan) where three readings were taken around the equator of the fruit (Meyer et al., 2008). Internal (avocado fruit only) and external photographs were taken at every sampling point using an SLR digital camera (model K100D, Pentax, Japan).

Real time endogenous ethylene levels were recorded for 10 min intervals in 'continuous flow' mode using an ethylene analyser device (Sensor Sense B.V., Nijmegen, the Netherlands) capable of measuring down to $0.3 \mathrm{~nL} \mathrm{~L}^{-1}$. Ethylene produced by avocado and strawberry fruit were analysed at every sampling point using a photoacoustic laser-based ethylene detector (EDT-300 real time ethylene analyser). The detector worked in conjunction with a valve control box allowing connection of up to six sampling cuvettes and a catalyser that enabled removal of ethylene or other hydrocarbons present in the atmosphere. At each sampling day, fruit samples were placed in glass cuvettes (with an empty jar as control) at a constant air flow of $4 \mathrm{~L} \mathrm{~h}^{-1}$. Ethylene production $\left(\mathrm{nL} \mathrm{h}^{-1}\right)$ was calculated by automatic integration with EDTsoftware and final measures expressed in terms of sample weight $\left(\mathrm{ng} \mathrm{kg}^{-1} \mathrm{~h}^{-1}\right)$

Firmness was measured using a uniaxial testing machine (model 5542, Instron, Norwood, MA, USA) equipped with a calibrated 500 or $5 \mathrm{~N}$ load cell, depending on the maximum loads recorded on the test day. One measurement was taken on the equatorial region 
of each fruit (skin was removed for avocado) (Landahl et al., 2009). Cylindrical probes of 8 and $4 \mathrm{~mm}$ diameter were used to measure maximal force at penetration (estimation of firmness $[\mathrm{N}])$ at a speed of $100 \mathrm{~mm} \mathrm{~min}^{-1}$ for avocado and strawberry, respectively.

Bruise and disease incidence and severity (strawberry only)

Disease incidence $(\%)$ was estimated as percentage of diseased fruit (over the total number of fruit) found in a punnet. Both incidence of bruising and severity (\%) was assessed based on four fruit selected per replicate, at random; bruise severity was recorded as percentage of the total fruit surface affected.

Internal discolouration (avocado only)

Incidence of internal flesh discolouration (\%) was recorded for all samples removed from storage, at each sampling point, according to Woolf et al. (2005).

\subsection{Statistical analysis}

Data were statistically analysed using Genstat for Windows version 16 (VSN International Ltd, Herts., UK). Analysis of variance (ANOVA) was used to identify the main effects of CA environment and storage time, and the interactions between these factors to a probability of $P<0.05$ unless otherwise stated. Least significant difference values (LSD $P_{0.05}$ ) are displayed. For avocado fruit, data was analysed without the shelf-life $\left(20^{\circ} \mathrm{C}\right)$ time points, when no significant differences were observed for the $5{ }^{\circ} \mathrm{C}$ trial and $20^{\circ} \mathrm{C}$ shelf-life combined In this case, two Least Significant Differences (LSD) values are provided $\left(5{ }^{\circ} \mathrm{C}\right.$ and $\left.5-20{ }^{\circ} \mathrm{C}\right)$.

\section{Results}

\subsection{Respiration rate}

Differential CA timings applied to strawberry and avocado during storage caused fluctuations in the real-time respiration rate (RR). Data was smoothed (using the 'running 
median algorithm' in SigmaPlot version 13.0, Systat Software, Inc.) and each measurement on the graph is representative of true variability (Figure 2).

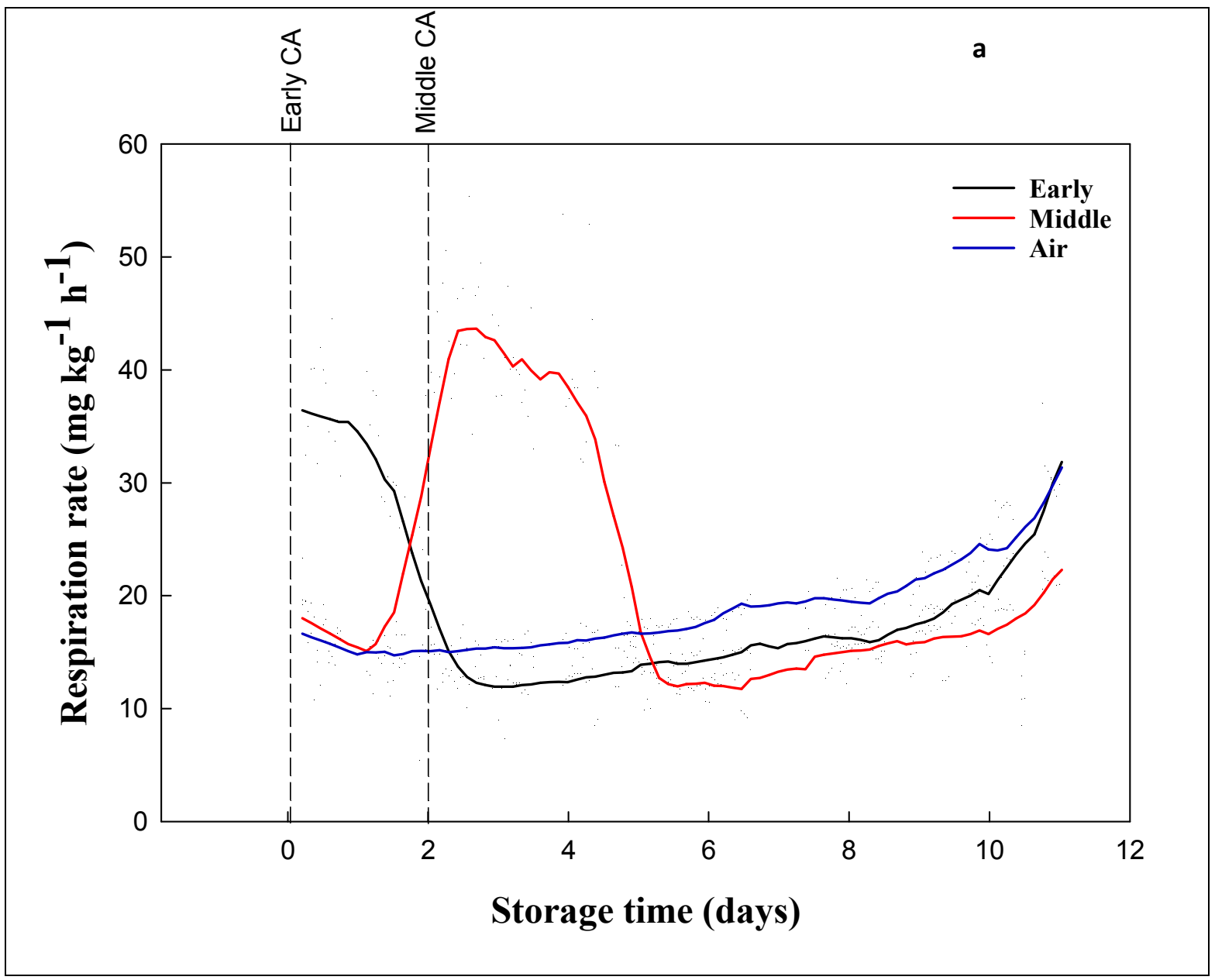




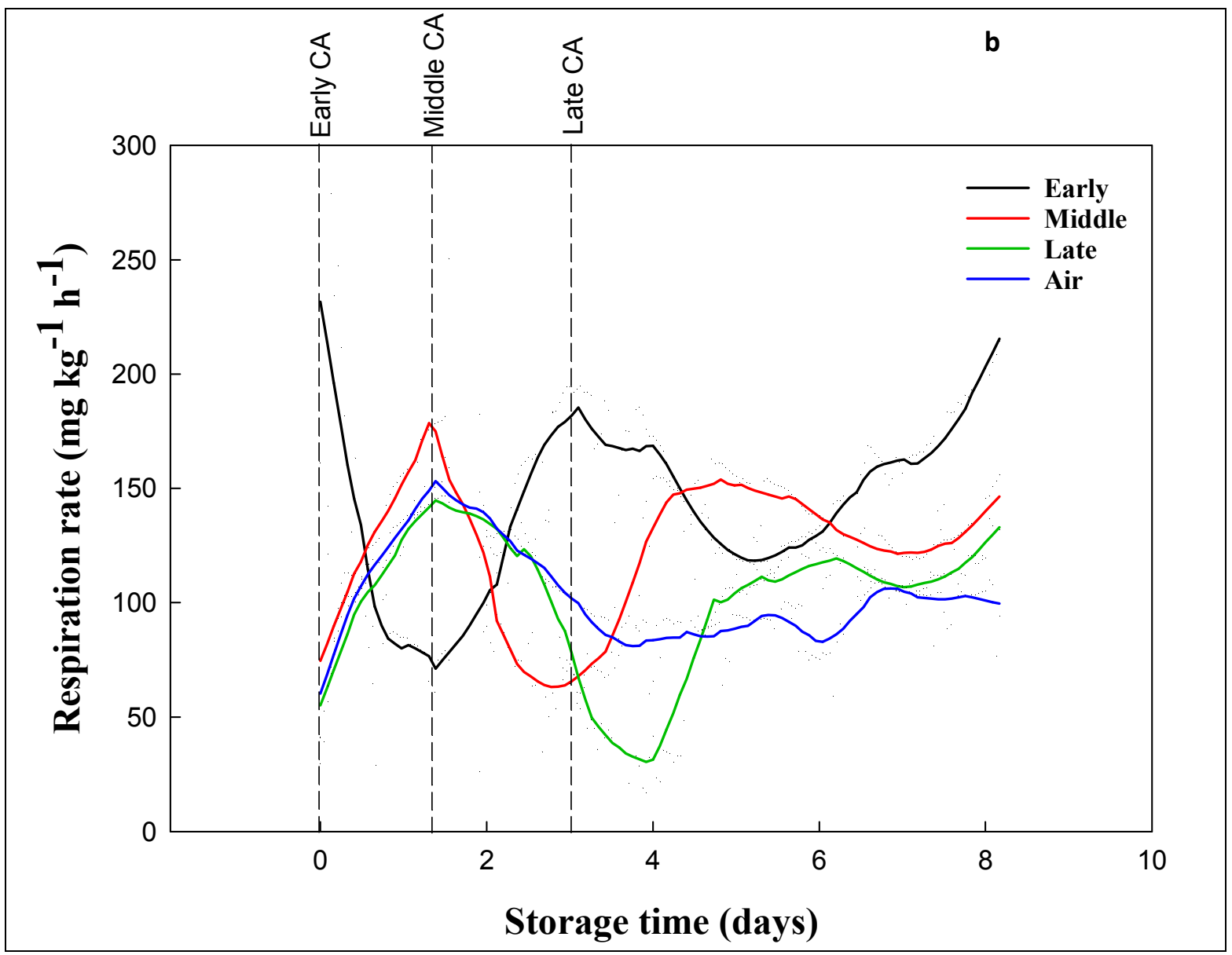

Figure 2. Real-time respiration rate $\left(\mathrm{CO}_{2}\right.$ production in $\left.\mathrm{mg} \mathrm{kg}^{-1} \mathrm{~h}^{-1}\right)$ of strawberry and avocado subjected to $\mathrm{CA}$ at different timings throughout storage; [a] applied $\mathrm{CA}(15 \mathrm{kPa} \mathrm{CO} 2+5 \mathrm{kPa}$ $\mathrm{O}_{2}$ ) for strawberry: $11 \mathrm{~d}$ at $5{ }^{\circ} \mathrm{C}(2 \mathrm{~d} \mathrm{CA}$ [early], $2.5 \mathrm{~d}$ after $2 \mathrm{~d}$ of air [middle] and air [control]); [b] applied CA (10 $\left.\mathrm{kPa} \mathrm{CO}_{2}+5 \mathrm{kPa} \mathrm{O}_{2}\right)$ for avocado: $9 \mathrm{~d}$ at $20^{\circ} \mathrm{C}(2 \mathrm{~d} \mathrm{CA}$ [early], $2 \mathrm{~d} \mathrm{CA}$ after $1.5 \mathrm{~d}$ of air [middle], $2 \mathrm{~d}$ CA after $3 \mathrm{~d}$ of air [late] and air [control]). Dots represent raw data points; lines represent smooth fit curves.

Real time respiration rate measurements for strawberry revealed a transient increase in $\mathrm{CO}_{2}$ production on transferral to the $\mathrm{CA}\left(15 \mathrm{kPa} \mathrm{CO} 2+5 \mathrm{kPa} \mathrm{O}_{2}\right)$ environment, but transferral back to an air environment caused respiration rates to decrease back to control levels (Figure 2a). In contrast, a steady increase in respiration occurred for air stored samples with no clear increase noted. 
For avocado, the respiration rate at $20^{\circ} \mathrm{C}$ in $\mathrm{CA}\left(10 \mathrm{kPa} \mathrm{CO}_{2}+5 \mathrm{kPa} \mathrm{O}\right)$ was lower after exposure to CA but values rapidly increased when they were removed from CA (Figure 2b). This is shown by the rapid decrease in respiration ( $c a$. from 228 to $76 \mathrm{mg} \mathrm{kg}^{-1} \mathrm{~h}^{-1}$ ) in early CA-treated fruit between 0 and $20 \mathrm{~h}$ before values increased again up to $c a .171 \mathrm{mg} \mathrm{kg}^{-1} \mathrm{~h}^{-1}$. For middle and late CA-treated avocados, respiration followed a similar trend to the controls (as CA had not yet been applied) where values reached up to $c a .142 .5 \mathrm{mg} \mathrm{kg}^{-1} \mathrm{~h}^{-1}$ before decreasing to $c a .95 \mathrm{mg} \mathrm{kg}^{-1} \mathrm{~h}^{-1}$. During this rise and fall, application of CA at middle and late timing resulted in respiration rates falling more rapidly, reaching lower values ( $c a .74$ and 38 $\mathrm{mg} \mathrm{kg} \mathrm{k}^{-1} \mathrm{~h}^{-1}$, respectively) compared to the control. As with early CA-treated avocado, the respiration rate increased after removal from CA storage with values returning to similar levels as that recorded at the time of initial CA application. Early CA-treated fruit also experienced a rise and fall in respiration as was observed in the control, but this was delayed by $c a .48 \mathrm{~h}$.

Discrete respiration rate measurements (at each sampling day) were performed on avocados stored at $5^{\circ} \mathrm{C}$ (data not shown). Early CA-treated avocado fruit were found to have significantly higher RR $\left(40-47 \mathrm{mg} \mathrm{kg}^{-1} \mathrm{~h}^{-1}\right)$ compared to the control $\left(23-32 \mathrm{mg} \mathrm{kg}^{-1} \mathrm{~h}^{-1}\right)$ after $20 \mathrm{~d}$ up to the end of cold storage (30 d); whereas mid and late CA-treated fruit had similar RR to the control.

\subsection{Ethylene production}

Ethylene production of middle CA-treated strawberries remained constant, and was the lowest, throughout storage ( $\left.c a .83-142 \mathrm{ng} \mathrm{kg}^{-1} \mathrm{~h}^{-1}\right)$ at $5{ }^{\circ} \mathrm{C}$ when compared to those exposed to early CA environment and the control (Figure 3). After $8 \mathrm{~d}$, there was a significant increase in ethylene production in both early CA-treated and control fruit; the mean ethylene values at the end of storage were ca. $427 v s .954 \mathrm{ng} \mathrm{kg}^{-1} \mathrm{~h}^{-1}$, respectively. 


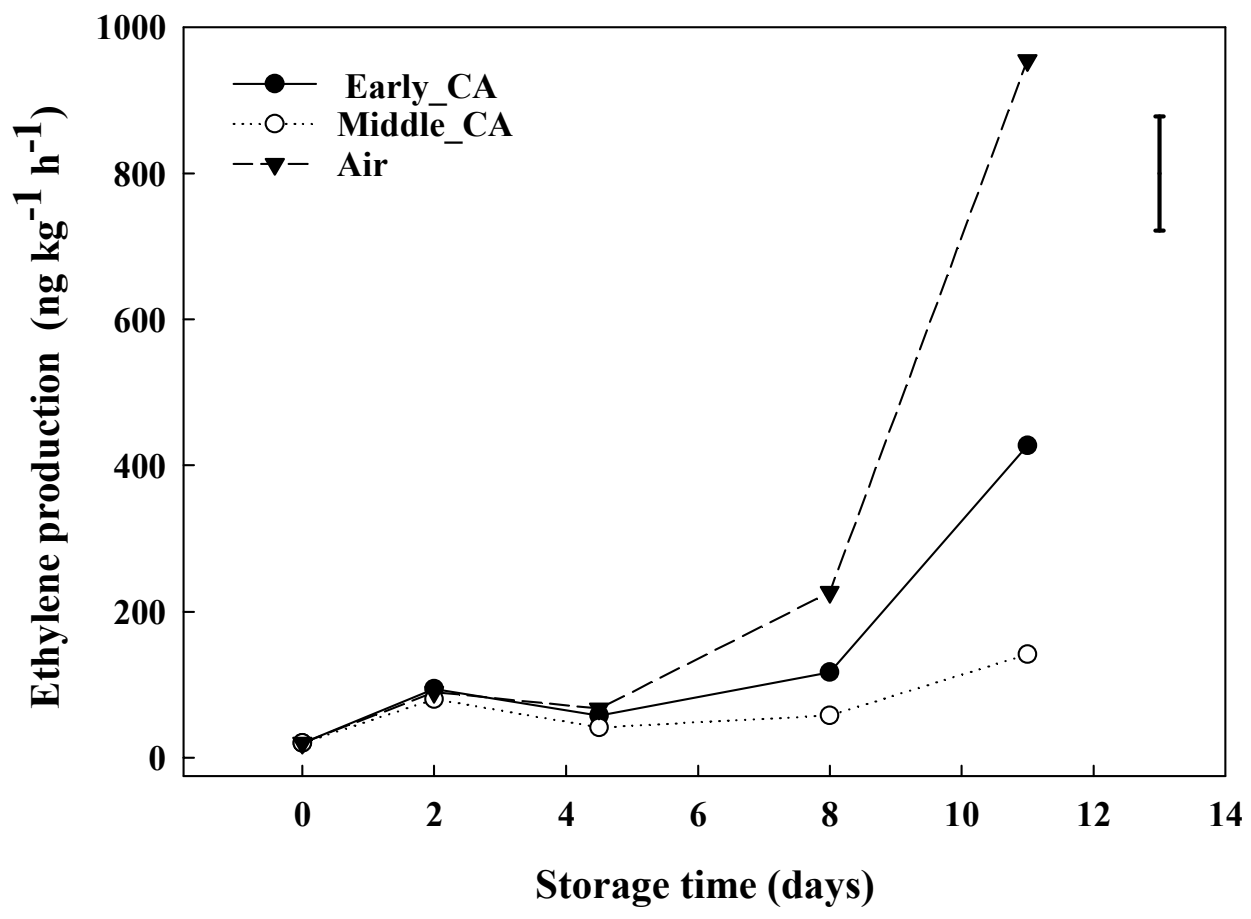

Figure 3. Ethylene production $\left(\mathrm{ng} \mathrm{kg}^{-1} \mathrm{~h}^{-1}\right)$ of strawberries subjected to $\mathrm{CA}$ at different timings throughout storage for $11 \mathrm{~d}$ at $5{ }^{\circ} \mathrm{C}\left(2 \mathrm{~d}\right.$ initial $15 \mathrm{kPa} \mathrm{CO}_{2} 5 \mathrm{kPa} \mathrm{O}$ [early], $2.5 \mathrm{~d} 15 \mathrm{kPa} \mathrm{CO}_{2}$ $5 \mathrm{kPa} \mathrm{O}_{2}$ after $2 \mathrm{~d}$ of air [middle] and air [control]). LSD bar $(P<0.05)$ for the interaction treatment $\mathrm{x}$ sampling day is shown.

Ethylene production of avocado was found to increase significantly (2-fold) in the first 2 $\mathrm{d}$ of storage and during the final $2 \mathrm{~d}$ at $20^{\circ} \mathrm{C}$. There was only a significant difference in ethylene production after $3 \mathrm{~d}$ storage at $20{ }^{\circ} \mathrm{C}$ where the early CA-treated fruit had higher ethylene production $5096.0 \mathrm{ng} \mathrm{kg}^{-1} \mathrm{~h}^{-1}(3.71 \log 10)$ than middle CA $106.5 \mathrm{ng} \mathrm{kg}^{-1} \mathrm{~h}^{-1}$ (2.03 log10) and late CA $294.5 \mathrm{ng} \mathrm{kg}^{-1} \mathrm{~h}^{-1}(2.47 \log 10)$ treated fruit, but not compared to the control $951.4 \mathrm{ng}$ $\mathrm{kg}^{-1} \mathrm{~h}^{-1}(2.98 \log 10)$ (Figure 4a). The sharp increase in ethylene production towards the end of storage occurred earlier (at day 5) for early CA-treated avocado compared to the control and mid and late CA-treated fruit (at day 7). 


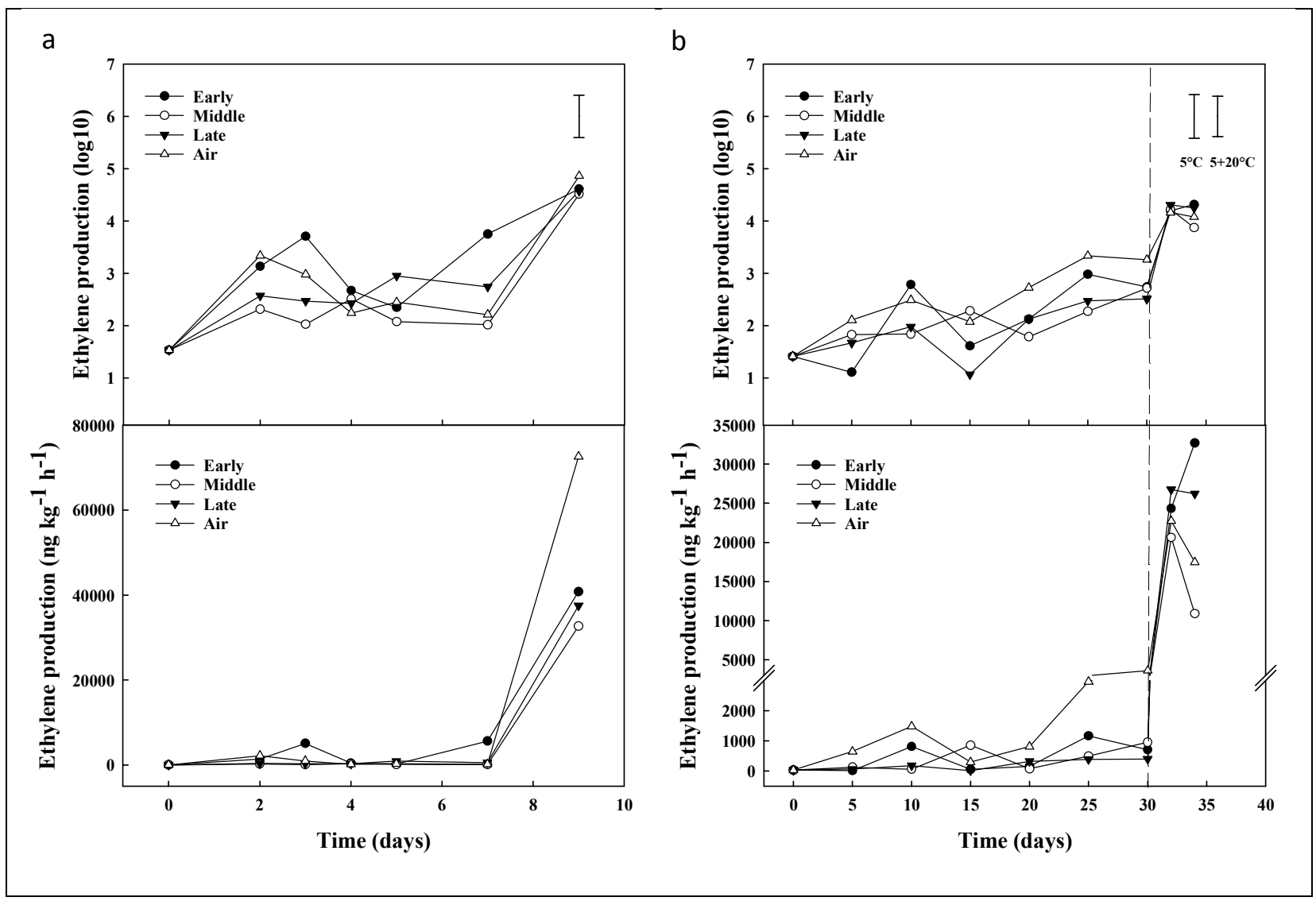

Figure 4. Ethylene production of avocado fruit subjected to $\mathrm{CA}\left(10 \mathrm{kPa} \mathrm{CO}_{2}+5 \mathrm{kPa} \mathrm{O}_{2}\right)$ at different timings throughout storage for [a] $9 \mathrm{~d}$ at $20{ }^{\circ} \mathrm{C}(2 \mathrm{~d}$ initial CA [early], $2 \mathrm{~d}$ CA after $1.5 \mathrm{~d}$ of air [middle], $2 \mathrm{~d} \mathrm{CA}$ after $3 \mathrm{~d}$ of air [late] and air [control]) [b] $30 \mathrm{~d}$ at $5{ }^{\circ} \mathrm{C}(5 \mathrm{~d}$ initial CA [early], $5 \mathrm{~d}$ CA after $5 \mathrm{~d}$ of air [middle], $5 \mathrm{~d}$ CA after $10 \mathrm{~d}$ of air [late] and air [control]) then transferred to $20^{\circ} \mathrm{C}$ for a further $4 \mathrm{~d}$ (shelf life; dashed line). LSD bars $(P<0.05)$ for the interaction treatment $\mathrm{x}$ sampling day are shown.

During cold storage of avocado at $5{ }^{\circ} \mathrm{C}$, ethylene production $(\log 10)$ steadily increased with no rapid increases observed following CA treatments (Figure 4b). Air stored avocado had higher overall ethylene values throughout storage, whereas middle CA-treated fruit had significantly lower ethylene production $3790.7 \mathrm{ng} \mathrm{kg}^{-1} \mathrm{~h}^{-1}$ (3.58 $\left.\log 10\right)$ compared to control 
$5559.9 \mathrm{ng} \mathrm{kg}^{-1} \mathrm{~h}^{-1}$ (3.75 $\left.\log 10\right)$ after $20 \mathrm{~d}$. No differences in ethylene production were observed during the $4 \mathrm{~d}$ shelf-life at $20^{\circ} \mathrm{C}$ following $30 \mathrm{~d}$ at $5{ }^{\circ} \mathrm{C}$.

\subsection{Bruise and disease incidence and severity}

Based on a disease incidence threshold of $2 \%$ (i.e. which equates to approximately one fruit with signs of damage/disease in 45), the time to first indication of disease was $8 \mathrm{~d}$ for the controls and the early CA-treated strawberries, and $11 \mathrm{~d}$ for the middle CA-treated fruit. Controls were also found to have the highest disease incidence (approximately $40-90 \%$ ) from 8 to $11 \mathrm{~d}$ (Figure 5a); whereas application of CA $\left(15 \mathrm{kPa} \mathrm{CO}_{2}+5 \mathrm{kPa} \mathrm{O}_{2}\right)$ midway through storage resulted in the lowest disease incidence with values significantly lower (7 \%) compared with the control $(26.0 \%)$. In contrast, an early CA application followed by air did not have any effect on the incidence of disease as values were similar to control.

Bruise severity sharply increased after day 5 (up to $40 \%$ of affected surface area) in control strawberries versus those $<2 \%$ for CA-treated fruit. Both CA-treated groups (early and middle) had similar bruise severity; this was lower (ca. 5 - 10\%) than control fruit, which were highly affected by day 11 in cold storage (40 \%) (Figure 5b).

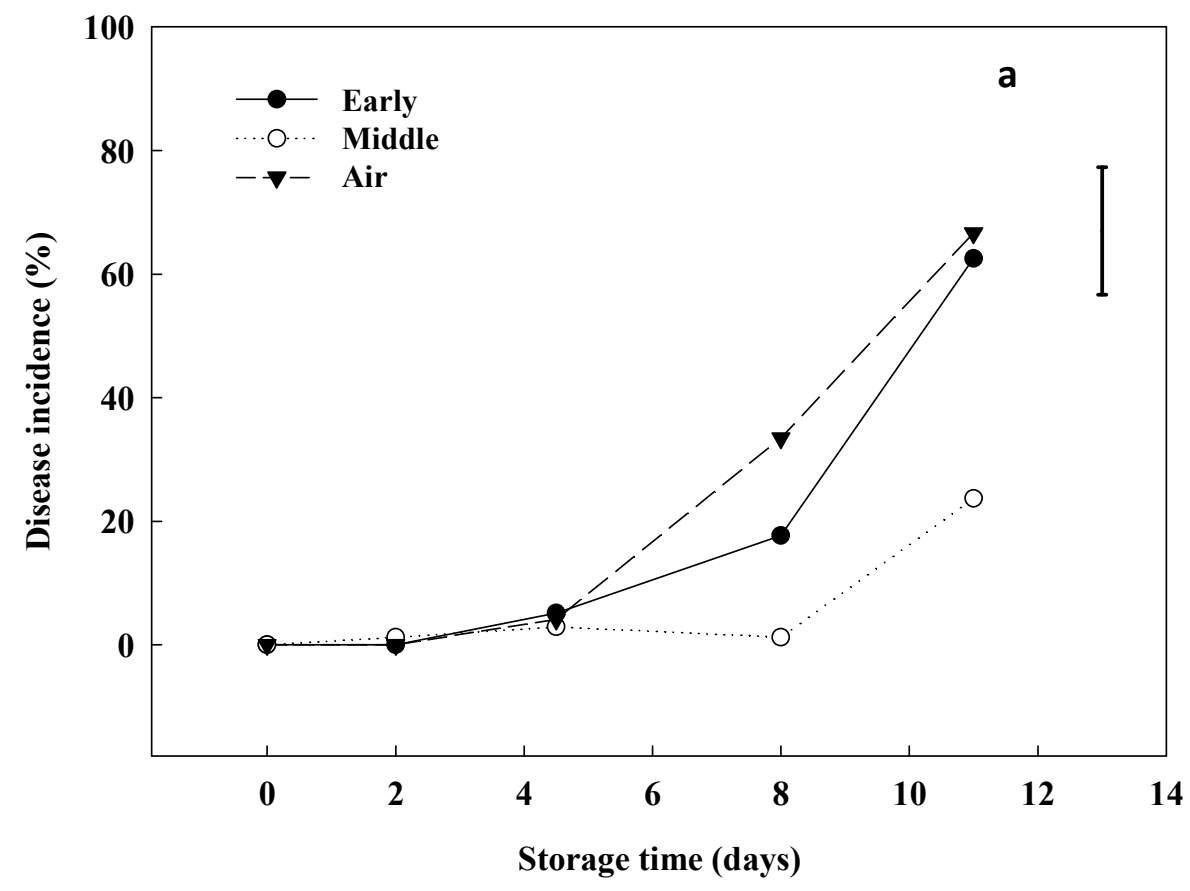




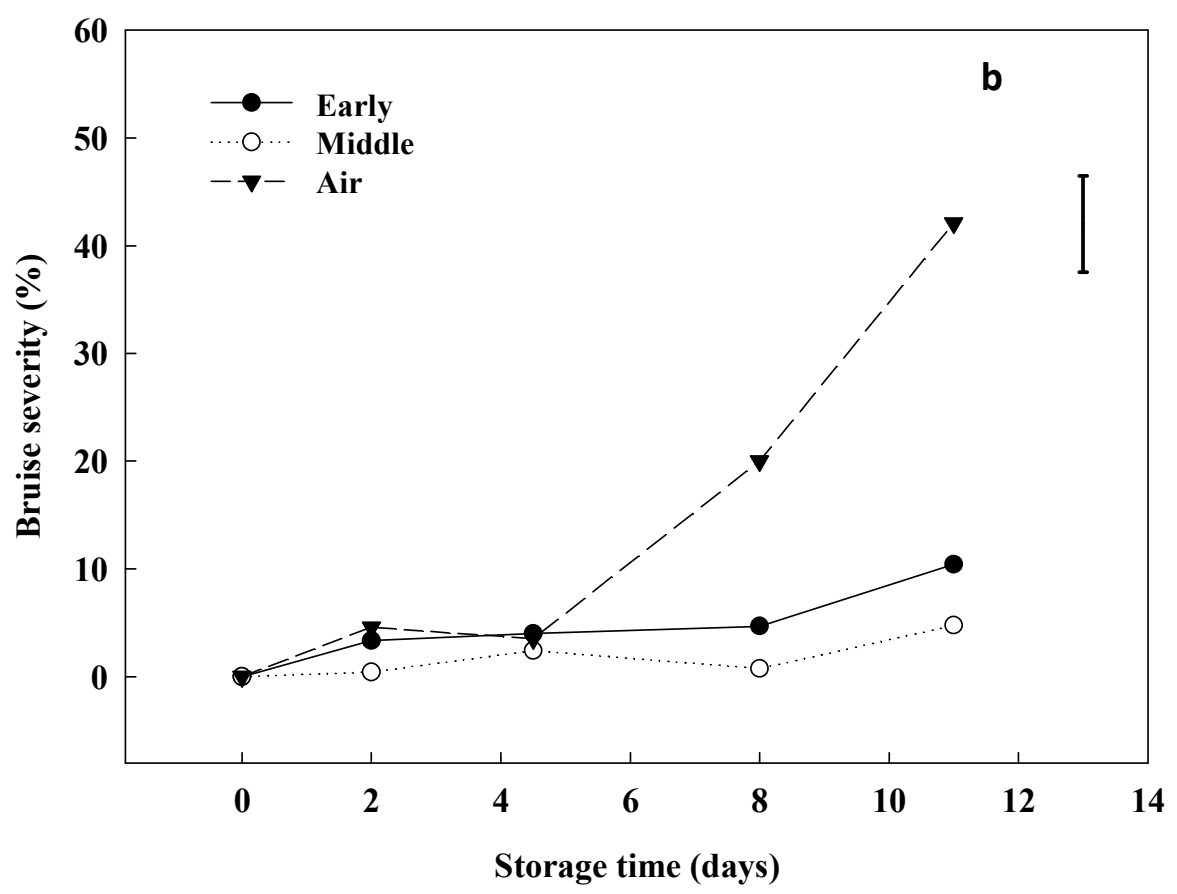

Figure 5. [a] Disease incidence (per punnet) and [b] severity (of affected area) of strawberry fruit stored under $\mathrm{CA}$ at different timings throughout storage for $11 \mathrm{~d}$ at $5{ }^{\circ} \mathrm{C}(2 \mathrm{~d}$ initial $15 \mathrm{kPa}$ $\mathrm{CO}_{2} 5 \mathrm{kPa} \mathrm{O}$ [early], $2.5 \mathrm{~d} 15 \mathrm{kPa} \mathrm{CO} 25 \mathrm{kPa} \mathrm{O}_{2}$ after $2.5 \mathrm{~d}$ of air [middle] and air [control]). LSD bars $(P<0.05)$ for the interaction treatment $\mathrm{x}$ sampling day are shown.

\subsection{Objective colour and internal discolouration}

Calyx and flesh colour in strawberry fruit was remained similarly during storage with slight differences between CA treatments (data not shown). Overall $\mathrm{L}^{*}$ of strawberry flesh was lowest for air treated fruit (42.45) whereas the middle CA-treated strawberries had higher L* (44.76). Both CA-treated fruit were more vivid compared to control, as indicated by overall higher $\mathrm{C}^{*}$ values (53 vs. 50, respectively). There was a significant interaction between treatment and time for strawberry calyx $\mathrm{h}^{\circ}$. At the end of the storage, both CA-treated fruit had similar $h^{\circ}$ values, while $h^{\circ}$ for control strawberries significantly decreased (106 vs. 111) at the end of storage indicating a less green calyx. 
During avocado storage at 20 and $5{ }^{\circ} \mathrm{C}$, a slow decrease in colour values $\left(\mathrm{h}^{\circ}, \mathrm{L}^{*}\right.$ and $\mathrm{C}^{*}$ ) was observed, indicative of ripening (Figure 6a). At $20{ }^{\circ} \mathrm{C}$, late CA-treated avocado appeared to be in a less ripened state compared to those stored in air as the $\mathrm{h}^{\circ}$ values were higher on days 2 (before CA applied), 7 and 9. This also coincided with higher overall values for $\mathrm{L}^{*}$ and $\mathrm{C}^{*}$ (brighter and intense colour). In contrast, early CA-treated fruit appeared to be in a more advanced stage of ripeness as indicated by lower $\mathrm{h}^{\circ}, \mathrm{L}^{*}$ and $\mathrm{C}^{*}$ values (less green, darker and duller in appearance), from day 5 to 9 , compared to the air stored fruit. Application of CA after $1.5 \mathrm{~d}$ (middle treatment) showed similar values to the controls.

Avocado treated with mid and late $\mathrm{CA}$ and subsequently stored at $5{ }^{\circ} \mathrm{C}$ appeared to be less ripe compared to control on days 20 to 30 as indicated by higher $h^{\circ}$ and overall higher values for $\mathrm{C}^{*}$ and $\mathrm{L}^{*}$ (Figure $\mathbf{6 b}$ ). In contrast, early CA-treated fruit experienced a more rapid drop in $\mathrm{h}^{\circ}$ with values similar to control on most days during storage except on days 20 and 30. However, once all CA samples were transferred to shelf life conditions $\left(4 \mathrm{~d}\right.$ at $\left.20{ }^{\circ} \mathrm{C}\right)$, colour became similar to controls. 

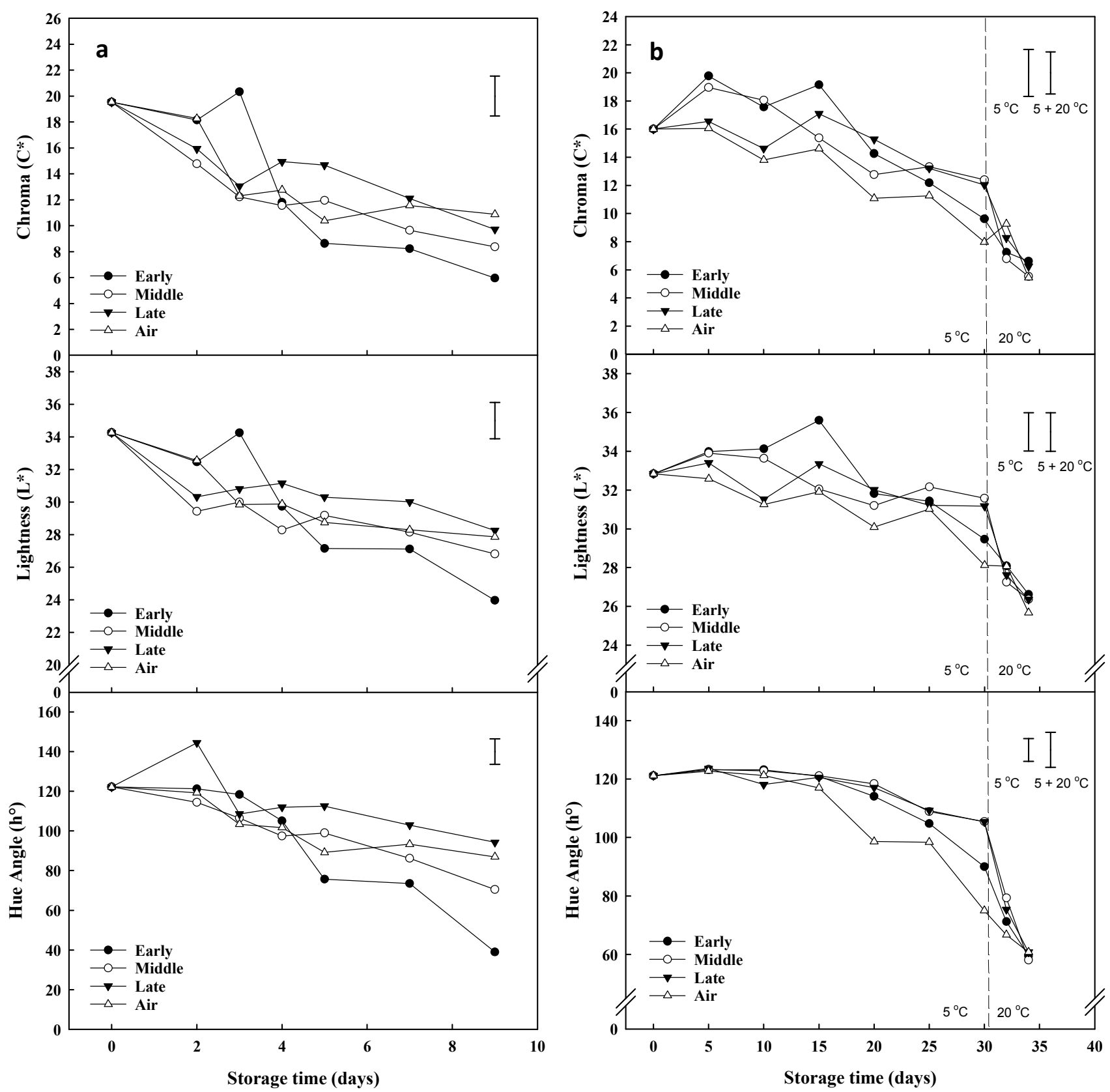

Figure 6. Objective colour $\left(\mathrm{L}^{*}, \mathrm{C}^{*}, \mathrm{~h}^{\circ}\right)$ of avocado fruit subjected to $\mathrm{CA}(10 \mathrm{kPa} \mathrm{CO} 2+5 \mathrm{kPa}$

$\left.\mathrm{O}_{2}\right)$ at different timings throughout storage for [a] $9 \mathrm{~d}$ at $20{ }^{\circ} \mathrm{C}(2 \mathrm{~d}$ initial CA [early], $2 \mathrm{~d}$ CA after $1.5 \mathrm{~d}$ of air [middle], $2 \mathrm{~d}$ CA after $3 \mathrm{~d}$ of air [late] and air [control]) [b] $30 \mathrm{~d}$ at $5{ }^{\circ} \mathrm{C}(5 \mathrm{~d}$ initial CA [early], $5 \mathrm{~d} \mathrm{CA}$ after $5 \mathrm{~d}$ of air [middle], $5 \mathrm{~d}$ CA after $10 \mathrm{~d}$ of air [late] and air [control]) then transferred to $20{ }^{\circ} \mathrm{C}$ for a further $4 \mathrm{~d}$ (shelf life). LSD bars $(P<0.05)$ for the interaction treatment $\mathrm{x}$ sampling day are shown. 


\subsection{Firmness}

Strawberry firmness tended to increase during or following CA treatment whereas there was no significant difference in firmness throughout storage for the control fruit (Figure 7a). During the first $2 \mathrm{~d}$ of storage, no significant difference was found for any of the treatments (ca. 1.2-1.3 N). However, from day 4 onwards, early CA-treated fruit were significantly firmer (by up to $c a .0 .6 \mathrm{~N}$ ) compared to control for the remainder of the storage period; while middle CA-treated fruit were significantly firmer from day 8 onwards (by up to $c a .0 .8 \mathrm{~N}$ ).

Initial firmness values for pre-climacteric avocado fruit were $c a .220 \mathrm{~N}$ before rapidly decreasing during $2 \mathrm{~d}$ of storage at $20^{\circ} \mathrm{C}$ (Figure $7 \mathbf{b}$ ). The firmness at time zero was in accordance with those reported by Meyer and Terry (2010) and Meyer et al. (2017) on preclimacteric 'Hass' avocado. Early CA-treated avocado fruit were firmer (ca. $97 \mathrm{~N})$ than the rest of the evaluated fruit $(\mathrm{ca} .40-50 \mathrm{~N})$ after $2 \mathrm{~d}$ at $20^{\circ} \mathrm{C}$ (Figure $\left.7 \mathbf{b}\right)$. By day 4 , there were no longer significant differences among treatments and control. When stored at $5{ }^{\circ} \mathrm{C}$, the early $\mathrm{CA}$ treatment was the only application that significantly resulted in better overall retained firmness $(114.8 \mathrm{~N})$ compared with the control $(97.3 \mathrm{~N})$. Firmness for the other two CA treatments was statistically similar to the control (data not shown).

Firmness of pre-climacteric avocado fruit (prior to CA application) harvested in December $\left(5{ }^{\circ} \mathrm{C}\right.$ trial) was similar $(c a .225 \mathrm{~N})$ to that observed for avocados harvested one month earlier (trial at $20^{\circ} \mathrm{C}$ ). Moreover, early CA-treated fruit showed the highest firmness up to $20 \mathrm{~d}$ of cold storage, compared to the control, after which no significant differences were found between treatments under cold storage or ripening period (Figure 7c). 

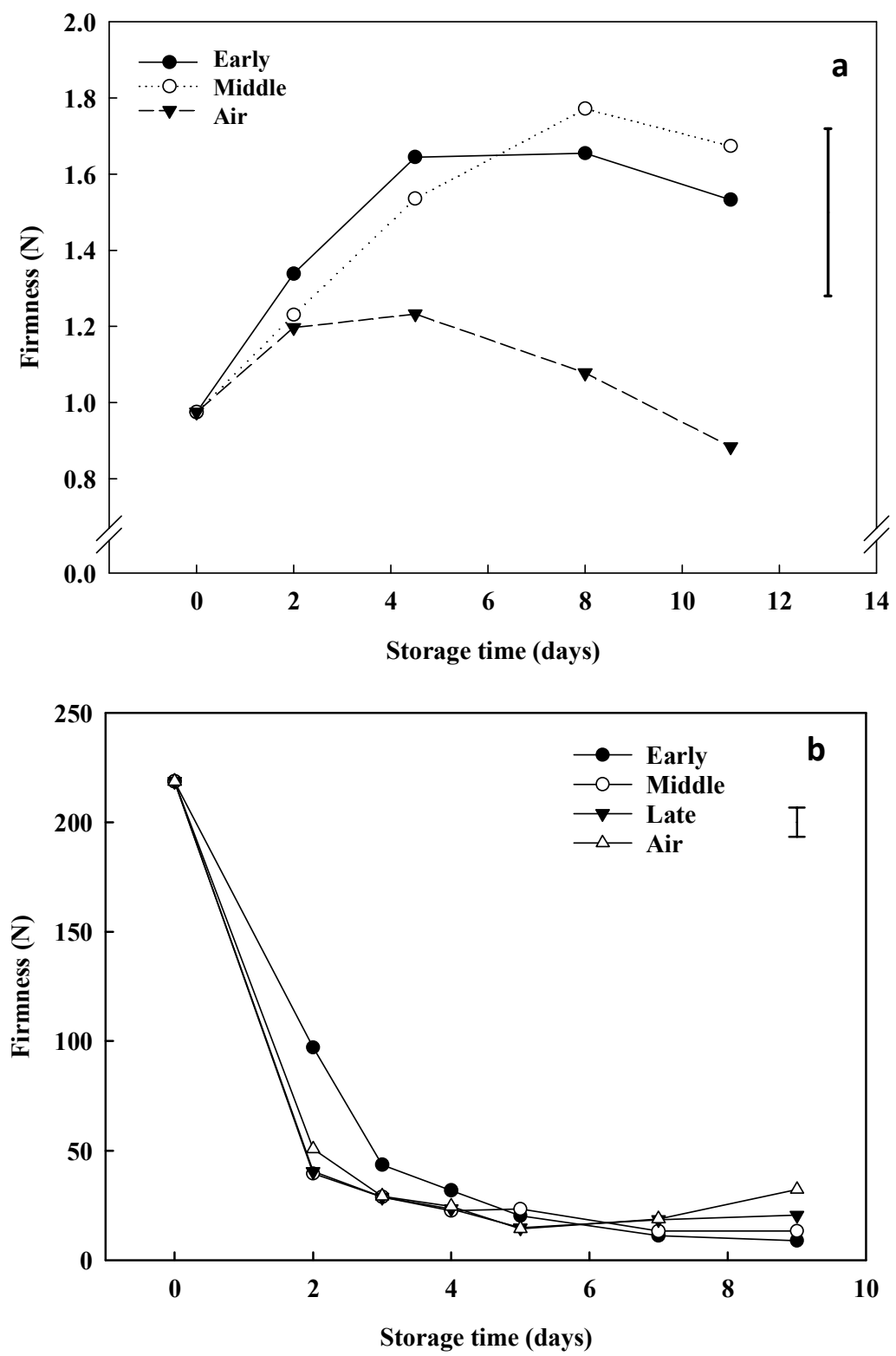


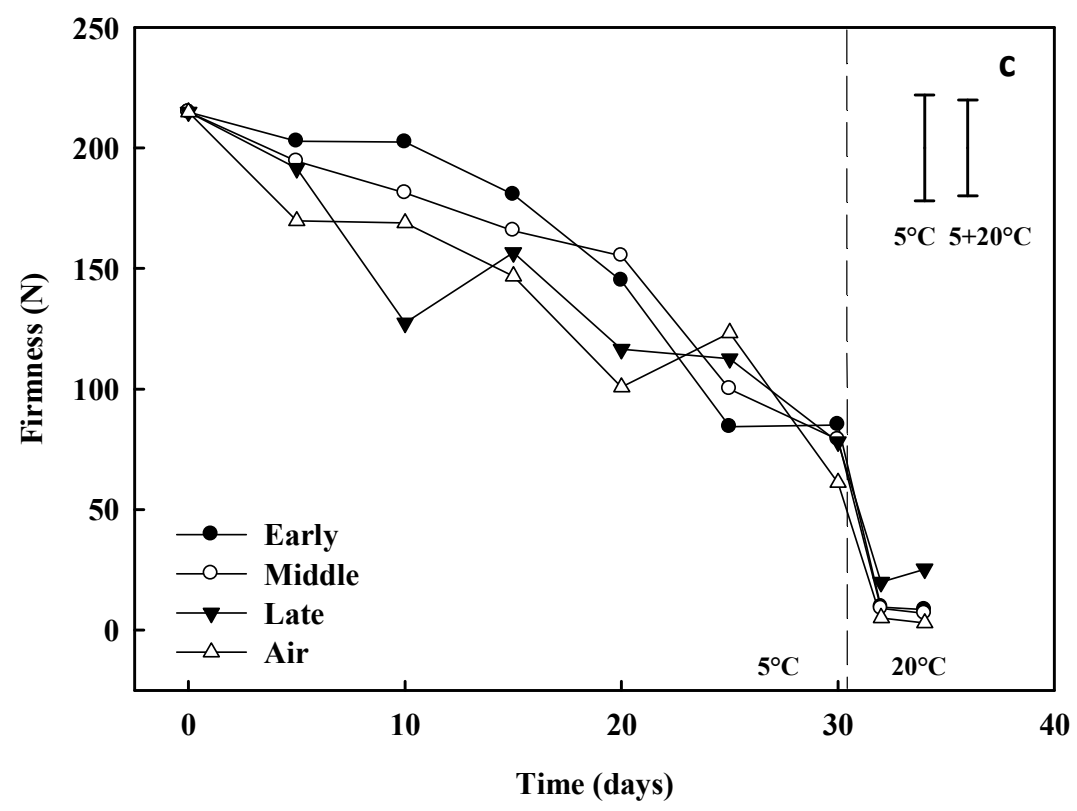

Figure 7. Firmness (N) of [a] strawberry fruit stored under $\mathrm{CA}\left(15 \mathrm{kPa} \mathrm{CO}_{2}+5 \mathrm{kPa} \mathrm{O} 2\right)$ at different timings throughout storage for $11 \mathrm{~d}$ at $5{ }^{\circ} \mathrm{C}(2 \mathrm{~d} \mathrm{CA}$ followed by air [early], $2.5 \mathrm{~d} \mathrm{CA}$ after $2 \mathrm{~d}$ of air [middle] and air only [control]); [b] avocado subjected to CA (10 $\mathrm{kPa} \mathrm{CO}_{2}+5$ $\left.\mathrm{kPa} \mathrm{O}_{2}\right)$ at different timings throughout storage for $9 \mathrm{~d}$ at $20{ }^{\circ} \mathrm{C}(2 \mathrm{~d} \mathrm{CA}$ [early], $2 \mathrm{~d} \mathrm{CA}$ after $1.5 \mathrm{~d}$ of air [middle], $2 \mathrm{~d} \mathrm{CA}$ after $3 \mathrm{~d}$ of air [late] and air only [control]); [c] avocado subjected to $\mathrm{CA}\left(10 \mathrm{kPa} \mathrm{CO} 2+5 \mathrm{kPa} \mathrm{O}_{2}\right)$ at different timings throughout storage for $30 \mathrm{~d}$ at $20{ }^{\circ} \mathrm{C}$ followed by $4 \mathrm{~d}$ at $20^{\circ} \mathrm{C}(5 \mathrm{~d}$ CA [early], $5 \mathrm{~d} \mathrm{CA}$ after $5 \mathrm{~d}$ of air [middle], $5 \mathrm{~d}$ CA after $10 \mathrm{~d}$ of air [late] and air only [control]). LSD bars $(P<0.05)$ for the interaction treatment $\mathrm{x}$ sampling day are shown.

\subsection{Discolouration}

Internal discolouration assessed at day 5 and 7 of storage at $20{ }^{\circ} \mathrm{C}$ was found to be similar in CA-treated avocados compared to control (Table 1). Contrastingly, after $9 \mathrm{~d}$ of storage at $20{ }^{\circ} \mathrm{C}$, early CA-treated avocados had significantly higher $\%$ discolouration compared to the control and mid/late CA treatments. For avocado stored at $5{ }^{\circ} \mathrm{C}$, minimal discolouration ( $c a .4 \%$ ) was observed after $5 \mathrm{~d}$ of cold storage (data not shown). Only at $20 \mathrm{~d}$ 
were significant differences noted between the middle CA-treated fruit which had significantly lower discolouration compared to the other treatments and control (Table 1). However, from $25 \mathrm{~d}$ of storage at $5{ }^{\circ} \mathrm{C}$, no differences in avocado discolouration were observed between treatments.

Table 1. Discolouration (\% of total internal cut area) of avocado subjected to $\mathrm{CA}(10 \mathrm{kPa} \mathrm{CO} 2$ $+5 \mathrm{kPa} \mathrm{O}$ ) at different timings throughout storage for $9 \mathrm{~d}$ at $20^{\circ} \mathrm{C}(2 \mathrm{~d} \mathrm{CA}$ [early], $2 \mathrm{~d} \mathrm{CA}$ after $1.5 \mathrm{~d}$ of air [middle], $2 \mathrm{~d}$ CA after $3 \mathrm{~d}$ of air [late] and air only [control]); for $30 \mathrm{~d}$ at 20 ${ }^{\circ} \mathrm{C}$ followed by $4 \mathrm{~d}$ at $20{ }^{\circ} \mathrm{C}(5 \mathrm{~d}$ CA [early], $5 \mathrm{~d}$ CA after $5 \mathrm{~d}$ of air [middle], $5 \mathrm{~d}$ CA after 10 $\mathrm{d}$ of air [late] and air only [control]). Values in brackets are square root transformations for statistical purposes. LSD $(\mathrm{P}<0.05)=1.502$ relates to transformed values only.

\begin{tabular}{lllll}
\hline $\begin{array}{l}\text { Storage } \\
\text { temperature }\end{array}$ & CA & After 5 d storage & After 7 d storage & After 9 d storage \\
\hline $\mathbf{2 0}^{\circ} \mathbf{C}$ & Early CA & $0.00(0.00)$ & $3.33(1.47)$ & $22.22(4.58)$ \\
& Middle CA & $5.00(1.65)$ & $1.67(1.04)$ & $2.78(1.61)$ \\
& Late CA & $5.00(1.65)$ & $1.58(0.88)$ & $0.00(0.00)$ \\
& Air & $1.11(0.61)$ & $4.44(1.22)$ & $0.78(0.70)$ \\
\hline $\mathbf{5}^{\circ} \mathbf{C}$ & LSD & 1.502 & & \\
& CA & After 20 d storage & After 25 d storage & After 30 d storage \\
& treatment & & & 51.11 \\
& Early CA & 21.67 & 48.89 & 35.28 \\
& Middle CA & 5.56 & 29.44 & 42.44 \\
& Late CA & 33.33 & 25.78 & 41.67 \\
& Air & 29.44 & 38.89 & \\
\hline LSD & 25.23 & & \\
\hline
\end{tabular}

\section{Discussion}

\subsection{Advantages of in situ real time respiration rate measurements under CA conditions}


The automated in situ set-up used herein allowed continuous recordings of real-time respiration measurements without disruption to the CA environment. This was deemed essential for obtaining more accurate and practically useful information comparable to real-life industry conditions. In addition, physiological effects were not influenced by handling or changes in temperature and/or CA. This is better than other flow through set-ups which are considered to be insufficiently accurate for measuring low respiration rates (Fonseca et al., 2002); in the present study, the $\mathrm{CO}_{2}$ detectors used were capable of accurately measuring down

to $1 \mu \mathrm{L} \mathrm{L}^{-1}$. Furthermore, multiple chambers were connected to the set-up allowing replicates to be stored under different CA conditions for simultaneous analyses in cycles, providing real time data sets with no disruptions over time. These data points could be plotted and smoothed to provide informed changes in respiration rate every hour under specific CA conditions.

\subsection{Differential effect of CA on metabolic and physiological changes during storage}

The metabolic rate of strawberry and avocado fruit was found to be differentially affected by CA timing depending on the produce type. Strawberry fruit experienced bursts in respiration rate while subjected to $\mathrm{CA}$ environments. This is in contrast to the literature which suggests that high $\mathrm{CO}_{2}$ levels reduce strawberry respiration rates (Fonseca et al., 2002; Almenar et al., 2006). Continuous monitoring under a CA environment enabled the detection of physiological changes throughout storage. Thus, the transient increase in RR detected immediately upon exposure to CA for both strawberry and pre-climacteric avocado may not have been captured using conventional methods, where respiration rate is normally recorded in a discrete way and after fruit acclimatisation following removal from a CA environment. An enhanced respiration rate typically accompanies high ethylene production (Merchante et al., 2013); yet this was not replicated for (non-climacteric) strawberry CA-treated fruit compared to the control. It is hypothesized, that the potential increase in ethylene preceding the peak in $\mathrm{CO}_{2}$ production may have occurred while under $\mathrm{CA}$ storage and therefore prior to the ethylene 
measurements. Moreover, the effects of CA on physiological changes have been shown to vary depending on the strawberry cultivar which could also differentially affect metabolic rate (Watkins et al., 1999). This phenomena may explain the observed discrepancies in the literature. Reduced exposure time to high $\mathrm{CO}_{2}$ levels may benefit strawberry fruit quality since fermentation products (acetaldehyde, ethanol and ethyl acetate) can accumulate after just one day of storage under high $\mathrm{CO}_{2}(20 \mathrm{kPa})$ (Watkins et al., 1999; Fernandez-Trujillo et al., 2007). Therefore, strawberry storage under high $\mathrm{CO}_{2}$ for short time periods may benefit the preservation of strawberry quality.

Contrastingly, RR of avocado stored at $20^{\circ} \mathrm{C}$ was reduced while under $\mathrm{CA}$ conditions as reported previously (Meir et al., 1995; Hertog et al., 2003). This reduction in metabolic rate was observed through quality indices, such as delayed softening in the early CA-treated fruit. Nevertheless, when CA exposure was removed, respiration returned to similar levels prior to the start of CA. Pre-treating avocado with high levels of $\mathrm{CO}_{2}$ for $48 \mathrm{~h}$ prior to cold storage (2$5^{\circ} \mathrm{C}$ ) has previously been shown to delay ripening as well as reduce incidence of chilling injury (CI) (Thompson, 2003). In contrast, exposing avocado to $3 \% \mathrm{O}_{2}$ and $97 \%$ nitrogen for $24 \mathrm{~h}$ (at $17^{\circ} \mathrm{C}$ ) diminished $\mathrm{CI}$, and reduced RR and ethylene production during subsequent storage at $2{ }^{\circ} \mathrm{C}$ (Pesis et al., 1994). There have been few studies centred on the impacts of CA on avocado, with the majority focused towards extending pre-climacteric storage life (Meir et al., 1995; Prabath et al., 2013; Basuki et al., 2016). However, the underlying mechanisms responsible for the observed metabolic changes during CA are not yet fully understood.

Strawberry and pre-climacteric avocado appeared to react similarly upon initial placement under CA conditions, where fruit showed a stress response reflected as a substantial increase in $\mathrm{CO}_{2}$ production. This behaviour differs from post-climacteric avocados, where the respiration decreased from the moment they were subjected to CA. This agrees with previous studies, where the application of abiotic treatments induced stress responses in pre-climacteric 
tomatoes and mango leading to increases in stress-related gene expression and respiration rate, respectively (Rothan et al., 1997; Rees et al., 2012).

Lower ethylene levels have been reported to reduce senescence and delay ripening in avocado (Meyer and Terry, 2010). Changes in metabolic rate are not widely assessed during CA storage as many studies focus on physiological changes during ripening. Basuki et al. (2016) measured respiration and ethylene during ripening at $20{ }^{\circ} \mathrm{C}$ following removal from CA. However, real time changes in metabolic rate during CA could provide additional information on the storability of particular batches of produce. For ethylene production, higher levels were recorded on day 3 during $20^{\circ} \mathrm{C}$ in early CA-treated avocado fruit, but in general, values were similar to the controls. For avocados stored at $5^{\circ} \mathrm{C}$, the beneficial effect of targeted mid CA treatment is supported by lower ethylene production whilst preventing an increase in RR.

\subsection{Effect of CA timing on ripening and senescence}

Despite rapid bursts in respiration following CA treatment, CA applied mid-way through strawberry storage was shown to maintain a more vibrant flesh colour, whilst calyx colour remained greener compared to control. Previous studies have reported lighter fruit colour after storage at high $\mathrm{CO}_{2}$ levels $(20 \mathrm{kPa})$ when applied at the beginning of storage (Watkins et al., 1999). Furthermore, after $8 \mathrm{~d}$ storage at $5{ }^{\circ} \mathrm{C}$ and regardless of application time, strawberries treated with $\mathrm{CA}\left(15 \mathrm{kPa} \mathrm{CO}_{2}+5 \mathrm{kPa} \mathrm{O}\right)$ were firmer compared with the control samples. Many studies have previously demonstrated an increase in strawberry fruit firmness following pre-treatments with high $\mathrm{CO}_{2}$ prior to storage (Watkins et al., 1999; Harker et al., 2010; Hwang et al., 2012). For example, Harker et al. (2010) applied high $\mathrm{CO}_{2}(10 \mathrm{kPa})\left(\mathrm{O}_{2}\right.$ levels were not given) to strawberries cv. Pajaro for an initial $3 \mathrm{~d}$ before transferral to atmospheric levels $\left(3\right.$ weeks at $0{ }^{\circ} \mathrm{C}$ ). The firmness was enhanced by high $\mathrm{CO}_{2}$ treatment which was suggested to be due to changes in apoplast $\mathrm{pH}$ enhancing cell-to-cell adhesion. The 
mechanism for increased firmness was further investigated by Hwang et al. (2012), who suggested that this was caused by pectin polymerisation mediated by calcium. Disease incidence in strawberry was also affected by the timing of the CA, which has not previously been examined. A continuous $\mathrm{CA}$ treatment of high $\mathrm{CO}_{2}\left(15 \mathrm{kPa}\right.$ for 5 or $14 \mathrm{~d}$ at $\left.5^{\circ} \mathrm{C}\right)$ alone was shown to be effective at reducing Botrytis rots (Wskelaki and Mitcham, 2003). However, the present study showed that only $2.5 \mathrm{~d}$ of CA was sufficient to extend the shelf-life of strawberries (based on disease incidence) by a further $3 \mathrm{~d}$.

Lower ethylene and respiration rate values in avocado CA stored fruit could indicate reduced sensitivity to cold storage $\left(5^{\circ} \mathrm{C}\right)$, since an increase in $\mathrm{RR}$ after storage is postulated to be triggered by chilling and coincides with incidence of $\mathrm{CI}$; symptoms of which include unusual changes/patterns in respiration rate and ethylene production, as well as failure to soften and ripen normally after cold storage (Basuki et al., 2016). However, despite normal fruit softening, internal discolouration of the mesocarp was observed in all samples, including the control, towards the end of cold storage. Therefore, CA storage did not hasten $\mathrm{CI}$ at $5^{\circ} \mathrm{C}$. Increases in ethylene production during avocado storage at $5^{\circ} \mathrm{C}$ was also observed at the end of storage, by which time, changes in colour and firmness were already evident. Increases in ethylene could therefore have been attributed to the occurrence of internal discolouration at the end of storage.

Application of early CA to avocado during storage (at $20^{\circ} \mathrm{C}$ ) was found to delay the climacteric peak in respiration which coincided with higher firmness levels, an indication that these fruit were less ripe; however, this was not reflected in colour measurements which showed these fruit were darker in colour. It is possible that the higher ethylene values recorded at day 3 in early CA-treated fruit only, may have hastened colour change; since avocado colour change is reported to be highly sensitive to ethylene (Meyer and Terry, 2010). However, together with the fact that firmness was maintained and percentage of internal discolouration 
of early CA-treated avocados was the highest among treatments, early CA treatment appeared to hasten sensitivity to CI. Previous work has also reported higher incidences of mesocarp discolouration in CA-stored avocados compared to regular air storage (Eksteen et al., 1998).

Mesocarp discolouration was more severe in samples subjected to extended storage at $5^{\circ} \mathrm{C}$ for $30 \mathrm{~d}$ (total storage time as 8 weeks [including transportation period]) compared to samples immediately stored at $20^{\circ} \mathrm{C}$ (total storage time 5 weeks). According to Woolf et al. (2005), 7 weeks is considered a long storage time and can be a significant challenge in terms of quality management. While, 4 weeks is not uncommon for exports from the Southern to Northern Hemisphere, disorders such as mesocarp discolouration can become a problem. Incorporating targeted CA was not found to reduce incidence of CI (mesocarp discolouration) and therefore did not extend the storage period beyond 3 additional weeks.

Application of different CA scheduling regimes during cold storage was also found to maintain colour. In addition, delaying the start of CA storage (viz. mid CA) was more effective in slowing colour change associated with ripening and reducing incidence of mesocarp discolouration up to $20 \mathrm{~d}$ of storage compared to early- and late-CA. Similar findings were reported on onion where delayed CA was just as beneficial at preventing sprout growth as continuous CA (Chope et al., 2007). However, for the experiment herein, additional shelf life assessments at this time point would be required to confirm potential commercial benefits of targeted CA mid-way through cold storage.

\section{Conclusions}

In conclusion, these results have shown that the targeted application of CA for just 2.5 $\mathrm{d}$ mid-way through storage at $5{ }^{\circ} \mathrm{C}(2.5 \mathrm{~d} ; 15 \mathrm{kPa} \mathrm{CO} 2+5 \mathrm{kPa} \mathrm{O} 2$ after $2 \mathrm{~d}$ in air $)$ increased strawberry shelf-life by $3 \mathrm{~d}$ (based on disease incidence). Furthermore, CA reduced endogenous ethylene production, and resulted in lighter, more vivid and firmer fruit suggesting 
a reduction in senescent decline. This has implications for modified atmosphere packaging of strawberry fruit where challenges lie in maintaining a desired atmosphere throughout shelflife.

The real-time respiration results for avocado fruit suggest that CA delays the climacteric peak and in general reduced ethylene production. The commercial application of early CA in avocado packaging suggests that shelf life could be extended by $2 \mathrm{~d}$ based on firmness. Conversely, storage of avocados at $5{ }^{\circ} \mathrm{C}$ would benefit from targeted mid-CA application as shown by better maintenance of colour and lower chilling injury incidence. It is evident that better scheduling CA treatments could be a more cost effective method for industry by, for example, reducing the amount and control of controlled respiratory gases required, yet effectiveness may be limited by the postharvest storage period. Further research into the optimum targeting of CA duration and concentration are needed to further enhance storage shelf-life and reduce postharvest losses.

\section{Acknowledgements}

This work was supported by Johnson Matthey Plc. The authors thank Drs Andrew Smith, Paola Zanetti, Andrew Cornish and Elizabeth Rowsell. Thanks also to Dr Natalia Falagán for technical discussions and assistance.

\section{References}

Almenar, E., Hernández-Muñoz, P., Laragón, J.M., Catalá, R., Gavara, R., 2006. Controlled atmosphere storage of wild strawberry fruit (Fragaria vesca L.). J. Agric. Food Chem. $54(1), 86-91$.

Barrios, S., Lema, P., Lareo, C., 2014. Modelling respiration rate of strawberry (cv. San Andreas) for modified atmosphere packaging design. Int. J. Food Prop. 17, 2039-2051. 
Basuki, E., McGlasson, W.B., Skurry, G., 2016. Polyamines association in textural changes of avocado during controlled atmosphere storage. Imp. J. Interdiscip. Res. 10(2), 17161721

Castellanos, D.A., Mendoza, R., Gavara, R., Herrera, A.O., 2017. Respiration and ethylene generation modelling of 'Hass' avocado and Feijoa fruits and application in modified atmosphere. Int. J. Food Prop. 20, 333-349.

Chope, G., Terry, L.A., White, P.J., 2007. The effect of the transition between controlled atmosphere and regular atmosphere storage on bulbs of onion cultivars SS1, Carlos and Renate. Postharvest Biol. Technol. 49, 61-68.

Collings, E., García Cas, J.A., Ordaz Ortiz, J. J., Terry, L.A., 2013. A new real-time automated method for measuring in-situ respiration rates of fresh produce. Acta Hortic. 1012, 11511157.

Eksteen, G.J., Bezuidenhout, J., Keevy, C., Reay, N., Robinson, R., 1998. The effect of intransit and storage conditions on the quality of avocados -1997 season, S. Afr. Avocado Growers' Assoc. Yearb. 21, 100-108.

Espinosa-Cruz, C.C., Valle-Guadarrama, S., Ybarra-Moncada, M., Martínez-Damián, M.T., 2014. Postharvest behavior of 'Hass' avocado fruit affected by temperature and microperforated based-modified atmosphere. Rev. Fitotec. Mex. 37(3), 235-242.

Fernández-Trujillo, J. P., Nock, J. F., Watkins, C. B., 2007. Antioxidant enzyme activities in strawberry fruit exposed to high carbon dioxide atmospheres during cold storage. Food Chem. 104 (4), 1425-1429.

Fonseca, S. C., Oliveira, F. A. R., Brecht, J. K., 2002. Modelling respiration rate of fresh fruits and vegetables for modified atmosphere packages: a review. J. Food Eng. 52, 99-119. 
Harker, F.R., Elgar, H.J., Watkins, C.B., Jackson, P.J., Hallet, I.C., 2000. Physical and mechanical changes in strawberry fruit after high carbon dioxide treatments. Postharvest Biol. Technol. 19, 139-146.

Hwang, Y.S., Min, J.H., Kim, D.Y., Kim, J.G., Huber, D.J., 2012. Potential mechanisms associated with strawberry fruit firmness increases mediated by elevated $\mathrm{pCO}_{2}$. Hortic. Environ. Biotechnol. 53(1), 41-48.

Hertog, M.L.A.T.M., Nicholson, S.E., Whitmore, K., 2003. The effect of modified atmospheres on the rate of quality change in 'Hass' avocado. Postharvest Biol. Technol. 29, 41-53.

Kader, A., 2002. Postharvest Technology for Horticultural Crops. Adel A. Kader, Technical editor by University of California, California, USA.

Landahl, S., Meyer, M.D., Terry, L.A., 2009. Spatial and temporal analysis of textural and biochemical changes of imported avocado cv. Hass during fruit ripening. J. Agric. Food Chem. 57, 7039-7047.

Meir, S., Akerman, M., Fuchs, Y., Zauberman, G., 1995. Further studies on the controlled atmosphere storage of avocados. Postharvest Biol. Technol. 5(4), 323-330.

Meir, S., Naiman, D., Akerman, M., Hyman, J.Y., Zauberman, G., Fuchs, Y., 1997. Prolonged storage of 'Hass' avocado fruit using modified atmosphere packaging. Postharvest Biol. Technol. 12, 51-60.

Merchante, C., Vallarino, J.G., Osorio, S., Aragüez, I., Villarreal, N., Ariza, M. T., Martinez, G.A., Medina-Escobar, N., Civello, M.P., Fernie, A. R., Botella, M A. and Valpuesta, V., 2013. Ethylene is involved in strawberry fruit ripening in an organ-specific manner. J. Exp. Bot. 64 (14), 4421-4439. 
Meyer, M.D., Terry, L.A., 2008. Development of a rapid method for the sequential extraction and subsequent quantification of fatty acids and sugars from avocado mesocarp tissue. $J$. Agric. Food Chem. 56, 7439-7445.

Meyer, M.D., Terry, L.A., 2010. Evaluation of shelf life and ripening of imported avocado 'Hass' fruit following treatment with E+ ${ }^{\circledR}$ Ethylene Remover or 1-methylcyclopropene (1-MCP) during medium-term cold storage. Acta Hortic. 877, 1049-1056.

Meyer, M.D., Chope, G.A., Terry, L.A., 2017. Investigation into the role of endogenous abscisic acid during ripening of imported avocado cv. Hass. J. Sci. Food Agric. 97, 36563664

Rees, D., Farrell, G., Orchard, J., 2012. Crop Post-Harvest: Science and Technology, Perishables. Blackwell Publishing Ltd. West Sussex, UK.

Rothan, C., Duret, S., Chevalier, C., Raymond, P., 1997. Suppression of ripening gene expression in tomato fruits subjected to high $\mathrm{CO}_{2}$ concentration. Plant Physiol. 114, 255263.

Pesis, E., Marinansky, R., Zauberman, G., Fuchs, Y., 1994. Prestorage low-oxygen atmosphere treatment reduces chilling injury symptoms in 'Fuerte' avocado fruit. HortSci. 29(9), 1042-1046.

Pesis, E., Ackerman, M., Ben-Arie, R., Feygenberg, O., Feng, X., Apelbaum, A., Goren, R., Prusky, D., 2002. Ethylene involvement in chilling injury symptoms of avocado during cold storage. Postharvest Biol. Technol. 24, 171-181

Prabath, P. U. A., Sekozawa, Y., Sugaya, S., Gemma, H., 2013. Change in lipid oxidation stability and antioxidant properties of avocado in response to 1-MCP and low oxygen treatment under low-temperature storage. Int. Food Res. J. 20 (3), 1065-1075. 
Terry, L.A., Ilkenhans, T., Poulston, S., Rowsell, L., Smith, A.W.J., 2007. Development of new palladium-promoted ethylene scavenger. Postharvest Biol. Technol. 45, 214-220.

Terry L.A., Mena, C., Williams, A., Jenney, N., Whitehead, P., 2011. Fruit and Vegetable Resource Maps - RSC-008.

Thompson, A.K., 2003. Fruit and Vegetables: Harvesting, Handling and Storage. Blackwell Publishing Ltd., Oxford, UK.

Valle-Guadarrama, S., Morales-Cabrera, M., Peña-Valdivia, C.B., Mora-Rodríguez, B., AliaTejacal, I., Corrales-García, J., Gómez-Cruz, A., 2013. Oxidative/fermentative behaviour in the flesh of "Hass" avocado fruits under natural and controlled atmosphere conditions. Food Bioprocess Technol. 6(1), 272-282.

Watkins, C. B., Manzano-Mendez, J. E., Nock, J. F., Zhang, J., Maloney, K. E., 1999. Cultivar variation in response of strawberry fruit to high carbon dioxide treatments. J. Sci. Food Agric. 79, 886-890.

Woolf, A.B., Requejo-Tapia, C., Cox, K.A., Jackman, R.C., Gunson, A., Arpaia, M.L., White, A., 2005. 1-MCP reduces physiological storage disorders of 'Hass' avocados. Postharvest Biol. Technol. 35, 43-60.

Wszelaki, A.L., Mitcham, E.J., 2003. Effect of combinations of hot water dips, biological control and controlled atmospheres for control of gray mold on harvested strawberries. Postharvest Biol. Technol. 27(3), 255-264. 